The $5^{\text {th }}$ International Conference on Family Business and Entrepreneurship

\title{
OPTIMIZING DIGITAL ONLINE TRAINING SATISFACTION TO GRAB DIGITAL ONLINE TRAINING BUSINESS OPPORTUNITY IN THE PANDEMIC CHALLENGE
}

\author{
Jazak Yus Afriansyah ${ }^{1 *}$, Anton Wachidin Widjaja ${ }^{2}$ \\ ${ }^{1,2}$ Faculty of Business, President University, Corresponding author: jazakyus@ gmail.com
}

\begin{abstract}
Several researches concluded roles of training including increasing the efficiency and compatibility of staff with the environment and consequently, improving service quality. Create job satisfaction and reduce conflict and disobedience, reduce absenteeism rates, other unnecessary costs and accidents, help improve individual performance and organizational effectiveness, develop talent, improve staff morale, facilitate the achievement of organizational goals. In the new normal conditions triggered by the COVID-19 pandemic which has occurred for more than 1 year in Indonesia, this also has an impact on training and learning activities so that the company transfers all training activities that are normally done face-to-face in class, replaced with digital and online training. This research is designed to see the relationship between the dimensions of online training participant satisfaction with online training referrals by participant to recommend the training to other employees to get online training business opportunities. This research was conducted through two methods in stages. The first one uses the exploratory method and continues by using the descriptive method. As the result of this research there is a significant relationship between the Online Training Dimension and Participant Training Satisfaction and Referral Training optimized to get greater opportunities to answer online training needs for companies, especially during the pandemic. This study has limitations, namely, research is only carried out under the ongoing Covid 19 pandemic, and research is carried out on a population of online training participants who attend training with a typical method.
\end{abstract}

Keywords: Roles of Training, Online Training, Organization Effectiveness

\section{Introduction}

Based on studies, Learning is defining as the process of gaining new understanding, knowledge, behavior, skills, values, attitudes, and insights, the ability to learn is possessed by humans. Some learning is immediate, caused by a single event, but many skills and knowledge are accumulated from repeated experiences (Karban, R., 2015).

In some contexts, there is often a confusion of understanding between Learning and Training, to understand more deeply the following is the definition of Training. The first definition of training was presented in the American Association for Training and Development (2021) as "training and development is a subspecialty of the fields of manpower in the organizations concerned with identifying, estimating and developing the main competencies of manpower (knowledge, skills and trends), through planned education, which helps individuals to perform their current and future jobs effectively".

Training is very important for the development of human resources in the company, because a training program that is consistent, regular and measurable will increase the competence and motivation of

1 
employees, with high competence and motivation they can work and perform well to achieve company goals (Urbancová et al., 2021).

Special study conducted by Khalili et al (2021) concluded several benefits of training programs for employees and companies, including increasing the efficiency and compatibility of staff with the environment and, consequently, improving service quality. Create job satisfaction and reduce conflict and disobedience, and abnormal behavior, and reduce absenteeism rates and other costs and accidents, help improve individual performance and organizational effectiveness, develop talent, and improve staff morale and stability in the organization, facilitate the achievement of organizational goals (M., Khalili, M., \& Mohseni, A.,2012).

During the Pandemic COVID 19, Digital Training that deliver by online has demonstrated significant and strategic roles in order to keep employee get motivated and yet well skilled to support them perform and achieve business goals (Rauch et al., 2021).

This research is designed to understand and see the relationship of the dimensions of online training participant satisfaction with online training referrals by participant to recommend the training to other employees to get online training business opportunities, especially during the current pandemic. A tool is made to measure perceptions that indicate the training participants satisfaction with the online training that has been followed.

\section{Theoritical Background and Hypothesis}

\section{Learning Theory}

As a basis for this research, several theories related to training in general, and specifically related to online training are presented, below are some related and relevant theories used.

The first theoretical basis for training is a research conclusion described training as a process to improve employees' knowledge, skills, abilities and attitudes in order to meet organizational objectives (Ismail et al., 2013). While the second theoretical basis is regarding performance improvement the study conducted by Gegenfurtner et al., (2013) defined training transfer as an application of the newly acquired knowledge in one's job.

In normal conditions, training is often given in the form of face to face in the classroom, where there is direct interaction between the trainer and the trainees. With a variety of training methods used, face-to-face training in the classroom has been shown to generally give participants satisfaction with the learning process (Handaru \& Mardiyati, 2014).

\section{Adult Learning Principles Theory}

The Adult Learning Principles Theory (Mirzadeh et al., 2020) was developed by Knowles and continues research has been carried out to date, below are some of the Adult Learning Principles that form the basis of this research; Adults really want to learn effectively only when they are free to direct their own learning and have a strong inside out motivation to develop a new skill or acquire a particular type of knowledge, this is considered as sustainable learning principle.

Experience learning is very important for adult and being in an inviting, collaborative and networking environment as an active participant in the learning process makes it efficient. They want to learn and making options based on their individual needs and the meaningful impact to the real-life situation (Loeng, S, 2012).

\section{Online Training}

There are several definitions that explain online learning, from some of these definitions it can be understood that they complement each other, below are some of these definitions.

According to "Teaching with Digital Technologies" by education.vic.gov.au. retrieved 2017-06-18 Digital learning is defined as any type of learning that is accompanied by technology or by instructional practice that makes effective use of technology. It encompasses the application of a wide spectrum of practices, including blended and virtual learning. Digital learning is sometimes confused with online learning or elearning; digital learning encompasses the aforementioned concepts.

According to the research conducted by Clark and Mayer (2016) in the textbook, they explain e-learning as instructions delivered through digital devices with the intent of supporting learning process and delivery. 
Meanwhile, according to in research published in journals that specifically discuss training, they defined online training is the e-learning as using information and communication technologies to for enabling access to online teaching and learning resources (Dhawan, 2020).

\section{Online Training Satisfaction}

Training expert on their recent studies defined training satisfaction as a measures the employees' feeling about the whole training activities such as identifying the training needs, designing the training program, delivering training contents, activating learning occurring, and assessing training evaluation (Omar, 2021). Based on the review and analysis of several related scientific references, it is stated that there are at least 6 dimensions of Online Training related to the satisfaction of training participants, especially online training, namely; Training Content, Training Concept, Training Materials, Training Delivery, Schedule of Training, Length of Training (Alsalamah, A., \& Callinan, C, 2021).

The following below is a definition for each of the dimension above, an explanation of the definition of each dimension is very important to make it easier to understand the limits and sizes along with the indicators that will be used in this research.

\section{Relationship Online Training Dimension and Online Training Satisfaction}

The existence of a mutually influencing relationship between the Online Training Dimension and Online Training Satisfaction, has been studied with more focus, especially as the impact of the Covid 19 Pandemic, below are several scientific reference studies that explain this relationship. Described by Tat, H.et al. (2021) in their research entitled The Quality and Satisfaction of Online Higher Education Environment, they said that the classic training dimension described by Kirkpatrick D. L in the past 40 years ago has not changed significantly as a dimension related to participant satisfaction, the difference is if the training is conducted online. There are other dimensions that can affect participant satisfaction, including the duration of the training, training schedule, and technical matters related to the quality of the internet network used by participants and trainers.

\section{Relationship Online Training Satisfaction and Training Referral}

The term referral training is very rarely used in the context of internal training within the company, because the term referral generally relates to recommendations or word of mouth for products or services that are sold, where satisfied consumers will recommend the product or service to others, this refers to the definition of the referral itself which means to recommend, the term that describes referrals quantitatively is Net Promoter Score (Colvin, Geoff.,2020). Thus, Referral Training means recommending training that has been followed to others, in the context of the company means recommending to internal colleagues, in the context of industry training recommending a training module to business partners or other companies. This is in accordance with a more specific definition of Training Referral namely, if current training participants recommend the training they are attended to their friends, colleagues, and family members (Jonathan, G,.2021).

Based on a review of some theories and references from the previous chapter, the following hypothesis can be proposed, namely:

Hypothesis 1 (H1) there is a relationship of online Training Content to the Training Participant Satisfaction, this is based on the study conducted by Urbancová, H.et al., (2021).

Hypothesis 2 (H2) there is a relationship of online Training Concept on the Training Participant Satisfaction, this is based on the study conducted by Urbancová, H.et al., (2021).

Hypothesis $3(\mathrm{H} 3)$ there is a relationship of online Training Materials on the Training Participant Satisfaction, this is based on latest data taken from the research of Bawa, M. S, (2021).

Hypothesis 4 (H4) there is a relationship of online Training Delivery on the Training Participant Satisfaction, this is based on the study conducted by Urbancová, H.et al., (2021).

Hypothesis 5 (H5) Schedule of Training has correlation with Participant Training Satisfaction, this is based on study conducted by Tat, H.et al. (2021).

Hypothesis 6 (H6) Length of Training has correlation with Participant Training Satisfaction, according the latest data taken from the research of Bawa, M. S, (2021).

Hypothesis 7 (H7) Training Satisfaction has correlation with Training Referral to other participant, scientific studies confirmed that there is a close relationship between customer satisfaction with products and services with a high likelihood of them recommending these products or services to others, while at the same time online training is a form of service, in this case it is a service provided by the Training Vendor 
to its users or consumers, which in this case are employees who are training participants (Reichheld, Fred; Markey, Rob., 2011).

The figure below describes the Research Model which is compiled based on a review of several scientific references above and is in accordance with the established Hypothesis:

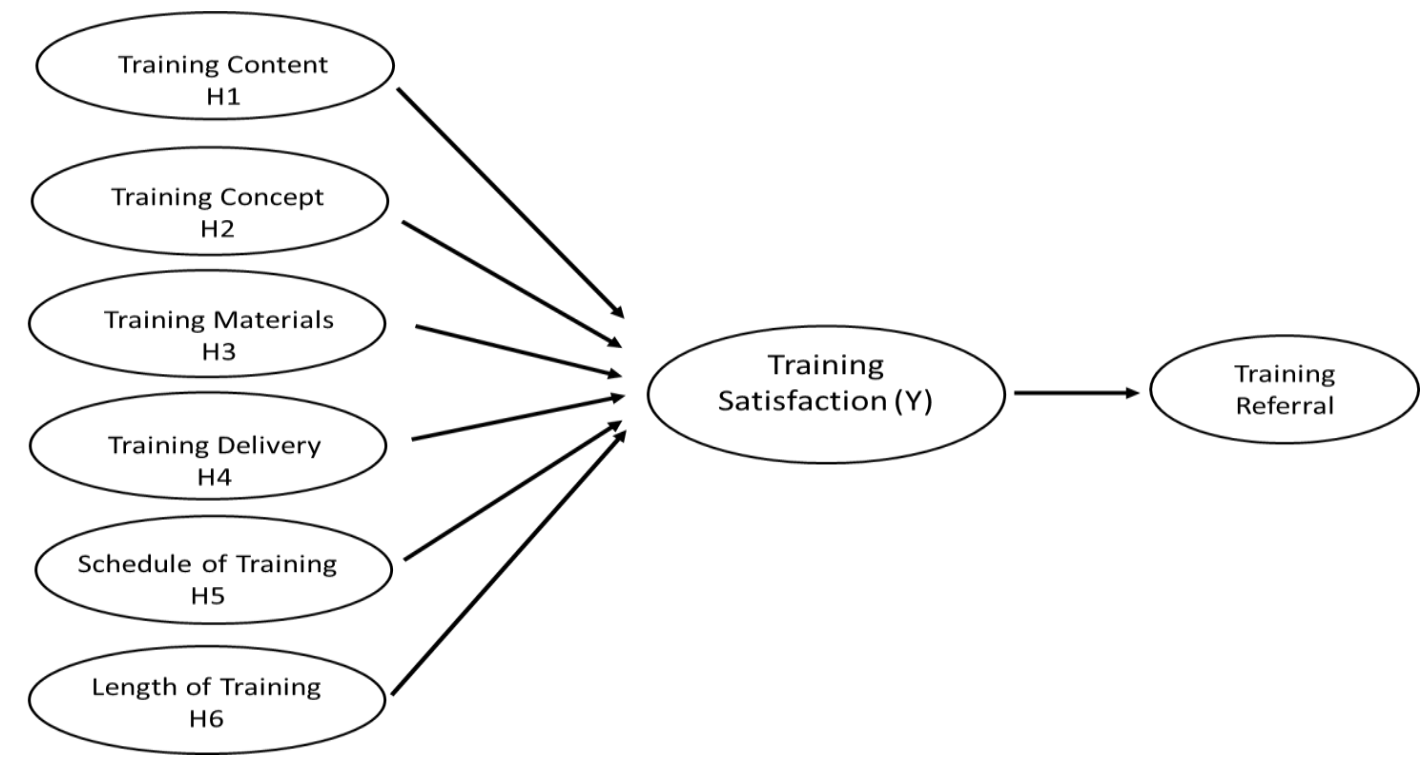

Figure 1 Research Model and Hypothesis 6 Online Training Independent variable that could influence Participant Satisfaction, Training Net Promoter Score/Referral.

(Source: Modified by the researcher, 2021)

\section{Method}

This type of research was chosen to obtain primary data, namely the main data taken directly from the research object and will be processed and analysed to prove the compiled hypothesis, descriptive research conducted is cross sectional. More specifically, using a single cross sectional, that is, only one sample of respondents is selected from the target population, and information from the sample is only taken once (Malholtra, 2007).

\section{Research Variable and Operational Definition}

To conduct this quantitative research, the variables that affect the satisfaction of the training participants must be defined and explained properly, in accordance with the previous explanation, while the variables used are; Training Content (Urbancová, H.et al.,2021), Training Concept (Urbancová, H.et al.,2021), Training Materials (Bawa, M. S,2021), Training Delivery (Urbancová, H.et al.,2021), Schedule of Training (Tat, H.et al., 2021), Length of Training (Bawa, M. S,2021).

\section{Collecting Data Method}

Population of respondents come from various company backgrounds or business types, namely: Telecommunication Company, State Owned Company, Consumer Goods Company, Pharmaceutical Company and Startup company. Respondents were randomized sampling in this study were training participants from several companies that took part in online training, a total of 144 respondents. The types or online training modules that participants participated in were: Fundamental Leadership Skills, Creative Problem Solving and Decision Making, Growing in Uncertainty, The 7 Habits of Highly Productive People, Leadership in Millennials and Time and Task Management Skills.

Online training is carried out using the Zoom Meeting Platform combined with a digital and social media training mix such as; WA Group, YouTube, Instagram, Kahoot, Google Form, Jamboard, Gaming, and competitions conducted during the online training.

All respondents attended Online Training for 6 hours per day with each training module delivered for 2 days or 12 hours of learning. In general, respondents are employees with various levels, ranging from entry level such as staff, middle level such as supervisor and first line manager then senior level such as senior 
manager to assistant vice president, and some are General Manager

Data were collected by giving questionnaires to online training participant after participant attended the training on the same day. The questionnaires were distributed online using Google Form and filled out by online training participant.

The following are some measuring tools in the form of questions in the questionnaire given to all virtual training participants. The respondent's answer in this case is that online training participants are quantified with a Likert scale of 1-5, where the score is $1=$ Strongly Disagree, $2=$ Disagree, $3=$ Fair, $4=$ Agree, $5=$ Strongly Agree

Data Analysis Method

Questionnaire result data is converted into code and entered into the program SPSS at this stage, the prepared hypothesis is ready to be tested. Data analysis method used in this research is multivariate analysis.

Result Analysis

Subsequent analysis uses statistical analysis by conducting a Spearman correlation test on research data with the following results:

Table 1. Spearman Correlation Test between variables

\begin{tabular}{|c|c|c|c|c|c|c|c|c|c|}
\hline \multicolumn{10}{|c|}{ Correlations } \\
\hline & & & \multirow[b]{2}{*}{ T_Content } & \multirow[b]{2}{*}{ T_Concept } & \multirow{2}{*}{\multicolumn{2}{|c|}{$\begin{array}{cc} & \text { T_Deliver } \\
\text { T_Materials } & \mathrm{y}\end{array}$}} & \multirow[b]{2}{*}{ Schedule } & \multirow[b]{2}{*}{ Length } & \multirow{2}{*}{$\begin{array}{c}\text { T_Referra } \\
1\end{array}$} \\
\hline & & & & & & & & & \\
\hline \multirow[t]{21}{*}{$\begin{array}{l}\text { Spearman's } \\
\text { rho }\end{array}$} & T_Content & $\begin{array}{l}\text { Correlation } \\
\text { Coefficient }\end{array}$ & 1.000 & $.800^{* * *}$ & $.689^{* *}$ & $.802^{* *}$ & $.702^{* *}$ & $.678^{* *}$ & $.631^{* *}$ \\
\hline & & Sig. (2-tailed) & . & .000 & .000 & .000 & .000 & .000 & .000 \\
\hline & & $\mathrm{N}$ & 144 & 144 & 144 & 144 & 144 & 144 & 144 \\
\hline & $\begin{array}{l}\text { T_Concep } \\
\mathrm{t}\end{array}$ & $\begin{array}{l}\text { Correlation } \\
\text { Coefficient }\end{array}$ & $.800^{* *}$ & 1.000 & $.831^{* *}$ & $.888^{* *}$ & $.782^{* *}$ & $.702^{* *}$ & $.615^{* *}$ \\
\hline & & Sig. (2-tailed) & .000 & . & .000 & .000 & .000 & .000 & .000 \\
\hline & & $\mathrm{N}$ & 144 & 144 & 144 & 144 & 144 & 144 & 144 \\
\hline & $\begin{array}{l}\text { T_Materia } \\
\text { ls }\end{array}$ & $\begin{array}{l}\text { Correlation } \\
\text { Coefficient }\end{array}$ & $.689^{* *}$ & $.831^{* *}$ & 1.000 & $.810^{* *}$ & $.618^{* *}$ & $.514^{* * *}$ & $.486^{* *}$ \\
\hline & & Sig. (2-tailed) & .000 & .000 & • & .000 & .000 & .000 & .000 \\
\hline & & $\mathrm{N}$ & 144 & 144 & 144 & 144 & 144 & 144 & 144 \\
\hline & $\begin{array}{l}\text { T_Deliver } \\
\mathrm{y}\end{array}$ & $\begin{array}{l}\text { Correlation } \\
\text { Coefficient }\end{array}$ & $.802^{* *}$ & $.888^{* *}$ & $.810^{* * *}$ & 1.000 & $.870^{* *}$ & $.715^{* *}$ & $.675^{* *}$ \\
\hline & & Sig. (2-tailed) & .000 & .000 & .000 & & .000 & .000 & .000 \\
\hline & & $\mathrm{N}$ & 144 & 144 & 144 & 144 & 144 & 144 & 144 \\
\hline & Schedule & $\begin{array}{l}\text { Correlation } \\
\text { Coefficient }\end{array}$ & $.702^{* *}$ & $.782^{* *}$ & $.618^{* *}$ & $.870^{* *}$ & 1.000 & $.634^{* *}$ & $.573^{* *}$ \\
\hline & & Sig. (2-tailed) & .000 & .000 & .000 & .000 & . & .000 & .000 \\
\hline & & $\mathrm{N}$ & 144 & 144 & 144 & 144 & 144 & 144 & 144 \\
\hline & Length & $\begin{array}{l}\text { Correlation } \\
\text { Coefficient }\end{array}$ & $.678^{* *}$ & $.702^{* * *}$ & $.514^{* *}$ & $.715^{* *}$ & $.634^{* *}$ & 1.000 & $.829^{* *}$ \\
\hline & & Sig. (2-tailed) & .000 & .000 & .000 & .000 & .000 & . & .000 \\
\hline & & $\mathrm{N}$ & 144 & 144 & 144 & 144 & 144 & 144 & 144 \\
\hline & $\begin{array}{l}\text { T_Referra } \\
1\end{array}$ & $\begin{array}{l}\text { Correlation } \\
\text { Coefficient }\end{array}$ & $.631^{* *}$ & $.615^{* *}$ & $.486^{* *}$ & $.675^{* *}$ & $.573^{* *}$ & $.829^{* *}$ & 1.000 \\
\hline & & Sig. (2-tailed) & .000 & .000 & .000 & .000 & .000 & .000 & . \\
\hline & & $\mathrm{N}$ & 144 & 144 & 144 & 144 & 144 & 144 & 144 \\
\hline
\end{tabular}

**. Correlation is significant at the 0.01 level (2-tailed).

Source: Primary data, processing by SPSS, 2021

In the Correlations table it can be read:

- The relationship between training content and the training concept is 0.0800 with a value of Sig.(2tailed) $0.000<0.05(5 \%)$ there is a significant relationship.

- The relationship between training content and training material is 0.689 with a value of Sig. (2tailed) $0.000<0.05$, there is a significant relationship and has a strong relationship.

- The relationship between training content and training delivery is 0.802 with a value of Sig.(2tailed) $0.000<0.05$, there is a significant relationship and has a very strong relationship. 
- The relationship between training content and training schedule is 0.702 with a value of Sig.(2tailed) $0.000<0.05$, there is a significant relationship, and has a strong relationship.

- The relationship between training content and length training is 0.678 with a value of Sig. (2tailed) $0.000<0.05$, there is a significant relationship, and has a strong relationship.

- The relationship between training content and training referrals is 0.631 with a value of Sig. (2tailed) $0.000<0.05$, there is a significant relationship, and has a strong relationship.

- The relationship between the concept of training and training materials is 0.831 with a value of Sig.(2-tailed) $0.000<0.05$, there is a significant relationship and has a very strong relationship.

- The relationship between the concept of training and delivery training is 0.888 with a value of Sig. (2-tailed) $0.000<0.05$, there is a significant relationship and has a very strong relationship.

- The relationship between the concept of training and the training schedule is 0.782 with a value of Sig.(2-tailed) $0.000<0.05$. There is a significant relationship and has a strong relationship.

- The relationship between the concept of training and length training is 0.702 with a value of Sig. (2-tailed) $0.000<0.05$, there is a significant relationship and has a strong relationship.

- The relationship between training concepts and training referrals is 0.615 with a value of Sig. (2tailed) $0.000<0.05$, there is a significant relationship and has a strong relationship.

\section{Discussion}

The results of the analysis above show that the dimensions of Training Content that have been carried out in online training which consist of variety of forms, including text, static, visual and video, audio, and interactive elements have an important role and are closely related to referral training, Furthermore, on the Training Concept dimension, which consists of The planned and programmed training designed to improve performance at the individual, group, and or organizational levels which was carried out in online training during this research, it has a role in forming a close relationship with trainee satisfaction with training referrals. Meanwhile, the Training Materials dimension consists of The materials prepared for use in training, fixed or unfixed, in any form, including, but not limited to, digital, print, audio, visual, or digital or printed content workbooks, data, concepts, exercises, and exams required have an important role in relation to referral training, the results above explain the role of the Training Delivery Dimension which consists of a process of communication in which information is transmitted to the learners. Some of the major methods are: lecture, audio visual, independent study, programmed, the learner interacts with the instructor, a computer/ simulator, or other trainees to practice the skills, on the job training, computer-based training, simulation, games, case analysis, role playing behavior modeling is important in relation to Referral Training, in the Training Schedule Dimension which consists of a plan that trainers compose in order to support your staff or project team with a necessary number of trainings. A training schedule embraces subjects such as: Calendar of trainings to be introduced to the staff. Course details and training agendas have a strong correlation with the Referral Training, then the Length of Training Dimension which is the duration of training is a quantitative component referring to the length in time of a training session. Training frequency refers to the number of training sessions within a given time frame, such as a day or a week has a close relationship with Referral Training, from the results of the above analysis simultaneously all Online Training Dimensions have a close relationship with Training Participants Satisfaction and Training Referrals. By paying attention to the results of the analysis above, any online training provided can focus on all the dimensions that have been discussed which are closely related to Participant Training Satisfaction and Referral Training by participants.

\section{Conclusion and Recommendation}

From the results of the analysis and discussion, it can be concluded that there is a close and significant relationship between the Online Training Dimension and Participant Training Satisfaction and Referral Training optimized to get greater opportunities to answer online training needs for companies, especially during the pandemic. Where Online Training is very necessary to ensure that all employees in the company still have stable Competence and Motivation that are useful to support their performance in achieving Business Goals, in addition to that, regular, measurable, and structured Online Training will provide positive benefits in general to all employees. relating to the company's operations, namely increasing the efficiency and compatibility of staff with the environment and, accordingly, improving service quality. Create job satisfaction and reduce conflict and disobedience, and abnormal behavior, and reduce absenteeism rates and other costs and accidents, help improve individual performance and organizational 
effectiveness, develop talent, and improve staff morale, where in the current challenging conditions everything in above is needed by the company to continue to survive and grow.

Referring to the conclusions above, it can be said that the Online Training Business opportunity will be very large as a logical impact of the increasing need for Online Training during the pandemic, and to optimize these business opportunities, getting Referral Training from online training participants who have participated in online training programs is very important and yet crucial because referrals are one of the many promotional mixes that can directly increase product or service sales, in this case Online Training services.

\section{References}

Alawajee, O. (2021). Influence of COVID-19 on Students Sign Language Learning in a TeacherPreparation Program in Saudi Arabia: Moving to E-Learning. 13(3).

Altowairiki, N. (2021). Online collaborative learning: Analyzing the process through living the experience. International Journal of Technology in Education (IJTE), 4(3), 413-427. https://doi.org/10.46328/ijte.95

Anderson, T. (2008). Toward a theory of online learning. In T. Anderson \& F. Elloumi (Eds.) Theory and Practice of Online Learning, Chapter 2 (pp. 45-74).

B, S. B. D., Hadjileontiadou, S. J., \& Diniz, J. A. (2021). FuzzyQoI-Based Estimation of the Quality of Interaction in Online Learning Amid Covid-19: A Greek Case-Study (Vol. 1). Springer International Publishing.

Bawa, M. S. (2021). Distance Learning During COVID-19 Pandemic in UAE Public Schools: Student Satisfaction, Attitudes and Challenges. 13(3)

Balula, A. (2021). Digital Platforms in the Age of Mobility: A Contribution Towards Language Teaching (Vol. 3). Springer International Publishing.

Bottini, S., \& Gillis, J. (2021). Use of an Online Training with Virtual Role Play to Teach Preference Assessment Implementation. Journal of Developmental and Physical Disabilities, 0123456789. https://doi.org/10.1007/s10882-021-09788-8

Bowe, Brian J.; Hoewe, Jennifer; Zeldes, Geri Alumit (2012). An Andragogical Approach to Developing Dialogic Learning through Wikis. Middle East Media Educator vol. 1 issue 2.

Brown, J.S., Collins, A. \& Duguid, S. (1989). Situated cognition and the culture of learning. Educational Researcher, 18(1), 32-42.

Baumgartner, Sharan B. Merriam, Rosemary S. Cafarella, Lisa M.; Caffarella, Rosemary S.; Baumgartner, Lisa M. (2007). Learning in adulthood: a comprehensive guide (3rd ed.). San Francisco: JosseyBass. p. 7. ISBN 978-0-7879-7588-3

Chini, J. J., Madsen, A., Gire, E., Rebello, N. S., \& Puntambekar, S. (2012). Exploration of factors that affect the comparative effectiveness of physical and virtual manipulatives in an undergraduate laboratory. Physical Review Special Topics - Physics Education Research, 8(1), 010113

Colvin, Geoff (2020). "The simple metric that's taking over big business". Fortune. Retrieved 3 June 2020.

Cascio Wayne F: Managing Human Resources. New York: McGraw Hill Inc. 1995; 245.

DeSimone, R. L., Werner, J. M \& Harris, D. M. 2002. Human resource development, Thompson Learning, Inc.

Daniel L. Schacter; Daniel T. Gilbert; Daniel M. Wegner (2011). Psychology, 2nd edition. Worth Publishers. p. 264. ISBN 978-1-4292-3719-2.

Ellington, J. K., Surface, E. A., Blume, B. D \& Wilson, M. A. (2015). Foreign Language Training Transfer: Individual and Contextual Predictors of Skill Maintenance and Generalization. Military Psychology. 27 (1): 36-51.

Fitriati, A., Anggoro, S., Harmianto, S., Bisnis, E., \& Purwokerto, U. M. (2021). Penguatan Pendidikan Karakter melalui Pelatihan Penggunaan Aplikasi Kindfull-Digital Character Book.

Grohmann, A., Beller, J\& Kauffeld, S. (2014). Exploring the critical role of motivation to transfer in the training transfer process. International Journal of Training \& Development. 18 (2).

Gegenfurtner, A., Veermans, K \& Vauras, M. 2013. Effects of computer support, collaborations and time lag on performance self efficacy and transfer of training: A longitudinal meta- analysis. Educational Research Review. 8: 75-89. 
Gerven, P. W., Paas, F., Merriënboer, J. J., Hendriks, M., \& Schmidt, H. G., , (2003) "The efficiency of multimedia learning into old age," British Journal of Educational Psychology, 73(4), 489-505

Hansman (2008) Adult Learning in Communities of Practice: Situating Theory in Practice.

Hernández-Perlines, F., Moreno-García, J., \& Yáñez-Araque, B. (2016). Training and business performance: the mediating role of absorptive capacities. SpringerPlus, 5(1). https://doi.org/10.1186/s40064-016-3752-6.

Handaru, A., \& Mardiyati, U. (2014). Jurnal Dinamika Manajemen. Jdm, 5(2), 171-182.

Ismail, A., Hua, N. K., Ismail, Y., Samah, A. J. A., Bakar, R. A., \& Ibrahim, N. (2015). Administrators' Roles in Training Programs and Training Transfer. Jurnal Dinamika Manajemen, 6(1), 25-39. https://doi.org/10.15294/jdm.v6i1.4294

Jasson, C. C., \& Govender, C. (2017). Measuring return on investment and risk in training - A business training evaluation model for managers and leaders. Acta Commercii, 17(1), 1-9. https://doi.org/10.4102/ac.v17i1.401

Jonathan, G,. (2021) Getting Clients and Referrals (Wealthy Fit Pro Guides)

John Bernardin H., and Joyce Russel, E.A., (1993) HRM: An Experiential Approach,(New York, McGraw Hill Inc.) pp-297

Kaspar, Wendy; Borgerding, Jodie (2017). "PRIMO: Peer-Reviewed Instructional Materials Online". College \& Research Libraries. 78: 2-7. doi:10.5860/crl.78.1.2.

Karban, R. (2015). Plant Learning and Memory. In: Plant Sensing and Communication. Chicago and London: The University of Chicago Press, pp. 31-44,

Kueh Hua, N., Ahmad, R \& Ismail, A. 2011. The Impact of the Supervisor's Role in Training Programmes on the Transfer of Training: A Case Study in Four East Malaysian Local Governments, Research and Practice in Human Resource Management. 19 (2): 24-42.

Kemper, K. J., Lynn, J., \& Mahan, J. D. (2015). What Is the Impact of Online Training in Mind-Body Skills? Journal of Evidence-Based Complementary and Alternative Medicine, 20(4), 275-282. https://doi.org/10.1177/2156587215580882

Kirkpatrick D L (1983), 'Four steps to measuring training effectiveness', Personnel Administrator, Vol. 28(11), pp. 19-25

Knowles, Malcolm (1980). The modern practice of adult education: From pedagogy to andragogy. Wilton, Connecticut: Association Press. ISBN 978-0695814724.

Knowles, Malcolm; Holton, E. F., III; Swanson, R. A. (2005). The adult learner: The definitive classic in adult education and human resource development (6th ed.). Burlington, MA: Elsevier. ISBN 9780750678377Loeng, S. (2012). Eugen Rosenstock-Huessy - an andragogical pioneer. Studies in Continuing Education, doi:10.1080/0158037X.2012.749850

Kirkpatrick D L (1996), 'Great ideas revisited: revisiting Kirkpatrick's four-level model', Training and Development, Vol. 50 (1), January, pp. 54-57

Landers, R. N., \& Callan, R. C. (2012). Training Evaluation in Virtual Worlds: Development of a Model. Journal For Virtual Worlds Research, 5(3). https://doi.org/10.4101/jvwr.v5i3.6335

Lewis, Beth (2018). "TLM or Teaching Learning Materials Definition". ThoughtCo. Archived from the original on 2018-04-14. Retrieved 2019-01-09.

Lave, J. (1988). Cognition in Practice: Mind, mathematics, and culture in everyday life. Cambridge, UK: Cambridge University Press.

Lave, J., \& Wenger, E. (1990). Situated Learning: Legitimate Peripheral Participation. Cambridge, UK: Cambridge University Press.

Laurillard, D. (2006). Rethinking University Teaching: a framework for the effective use of learning technologies. Abingdon, Oxon., RoutledgeFalmer

Mousavi, S. Y., Low, R., \& Sweller, J., (1995) "Reducing cognitive load by mixing auditory and visual presentation modes, "Journal of educational psychology, 87(2), 319.

Michele N. Medina. (2017) Training motivation and satisfaction: The role of goal orientation and offshoring perception. Personality and Individual Differences 105, pages 287-293.

Morgado, L., Varajão, J., Dominguez, C., Oliveira, I., \& Sousa, F. (2014). Balancing European SME Managers' Training Contents: Perceived Importance \& Training Needs. Business Systems Research Journal, 5(2), 4-22. 